\title{
A model to determine effective HIV/AIDS and Multi-Drug Tuberculosis (MDRTB) treatment policies: a case study from the Russian Federation
}

Reda Lebcir

From $16^{\text {th }}$ International Symposium on HIV and Emerging Infectious Diseases

Marseille, France. 24-26 March 2010

\section{Background}

The explosive increase in the number of people infected with tuberculosis, multi drug resistant tuberculosis (MDRTB), and injecting drug users (IDU) HIV/AIDS has become a serious public health challenge in Russia. The World Health Organization (WHO) is recommending policies including simultaneous use of highly active antiretroviral therapy (HAART) to treat HIV/AIDS and second line drugs to treat MDRTB. However, it is not clear what would be the impact of implementing these recommendations on tuberculosis and HIV/AIDS mortality. In this context, the aim of this research is to quantify the consequences of adopting these policies in terms of deaths reduction.

\section{Methods}

A System Dynamics (SD) computer simulation model was developed to represent the dynamic transmission of tuberculosis, MDRTB, and HIV/AIDS. The model represented explicitly the complex interactions between these diseases and how these link to their transmission and spread in the population. The model simulated scenarios, over a 20 years period, regarding MDRTB cure rate and the fraction of HIV/AIDS patients covered by HAART.

\section{Results}

The results over a 20 year period indicate that reduction in tuberculosis and HIV associated tuberculosis deaths would be negligible for HAART coverage up to $50 \%$. The reduction is only significant for HAART coverage of $70 \%$ and above. Similarly, high MDRTB cure rate

\footnotetext{
Correspondence: m.r.lebcir@herts.ac.uk
}

University of Hertfordshire, Hatfield, UK reduces significantly deaths from tuberculosis and MDRTB and this reduction is more important as the HAART coverage is increased.

\section{Discussion}

This research demonstrates, through a computer simulation model, that policies recommended by the WHO will not be effective unless HAART coverage is ramped up to include a sizeable fraction of HIV/AIDS patients. This will have to be coupled with an extensive use of second line drugs to address MDRTB. It is only through combination of these policies that tuberculosis and HIV/AIDS mortality could be reduced significantly.

Published: 11 May 2010

doi:10.1186/1742-4690-7-S1-P157

Cite this article as: Lebcir: A model to determine effective HIV/AIDS and Multi-Drug Tuberculosis (MDRTB) treatment policies: a case study from the Russian Federation. Retrovirology 2010 7(Suppl 1):P157.

Submit your next manuscript to BioMed Central and take full advantage of:

- Convenient online submission

- Thorough peer review

- No space constraints or color figure charges

- Immediate publication on acceptance

- Inclusion in PubMled, CAS, Scopus and Google Scholar

- Research which is freely available for redistribution

Submit your manuscript at www.biomedcentral.com/submit 